
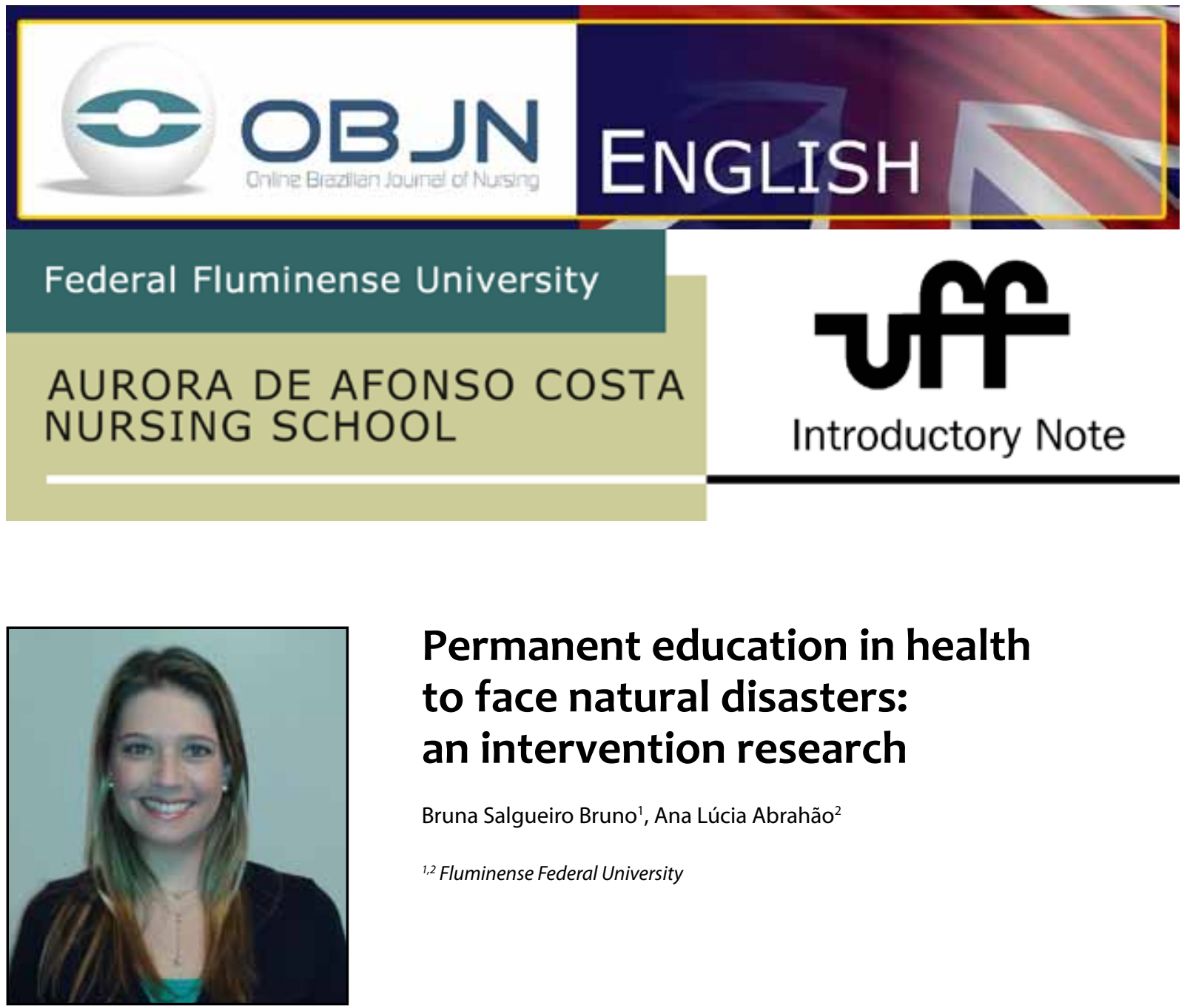

\title{
Permanent education in health to face natural disasters: an intervention research
}

\author{
Bruna Salgueiro Bruno', Ana Lúcia Abrahão² \\ 1,2 Fluminense Federal University
}

\section{ABSTRACT}

This study has as a primary aim to analyze the Situational Strategic Plan (SSP) with regard to a Family Health team, as a device for Permanent Education in Health (PEH) in order to deal with natural disasters. The method to be used is intervention research which adopts a qualitative approach, in which we will use the SSP as a PEH device, in order to guide the Family Health team when it comes to planning the actions in health. The analysis of data will occur based on the observation of four stages of the SSP, and in accordance with the analysis of the content, seen as a set of techniques of communication analysis. It is expected that the implementation of the SSP will be capable of generating other guiding instruments that assist the teams in undertaking territorial actions to face natural disasters, in order to deal with such conditions in a more holistic and resolute manner.

Descriptors: Natural Disasters; Continuing Education; Strategic Planning. 


\section{PROBLEM SITUATION AND ITS SIGNIFICANCE}

The natural disasters that affected the mountainous region of the Brazilian state of Rio de Janeiro in 2011 and 2012 left a scar in the cities, destroying the homes and lives of thousands of people. Many Family Health teams were needed to assist the affected population. However, based on the unexpected scenario and the lack of preparedness of these professionals, as well as the lack of previous knowledge which would help them to face such situations, the population was largely abandoned, with health professionals having to improvise and, in many occasions, dealing with the situation based on empirical data. The lack of strategies to deal with such disasters that had never been experienced before, lead to tecnicist and not so resolute health actions. When the Situational Strategic Plan (SSP) is incorporated in terms of the actions of Family Health teams, and involves the following stages: normative; explicative; strategic and tactical-operational, which permit the creation of new formats to face these situations, and becomes a device in the context of Permanent Education in Health (PEH).

$\mathrm{PEH}$ is based on meaningful learning, and it can be understood as learning-working, as it is done from the point of view of problems faced in the reality of the professionals. It also takes into consideration the understandings and the experiences that the people involved already have. It makes the professionals responsible for their own education, and it aims to achieve individual and collective competency, in addition to strengthening professional categories, and as a consequence, the whole health team ${ }^{(1)}$.

The Brazilian National Policy of Permanent Education in Health ${ }^{(2)}$ considers PEH as an important representation needed to change the concepts and the practices associated with the education of health professionals. From this perspective, $\mathrm{PEH}$ incorporates teaching and learning into the daily lives of the organizations involved, in their real context; the educative strategies emerge from daily practice as sources of information and of experienced problems, problematizing the practices and guiding the actors to the reflection of their own practice.

This study is justified by the negative experience of a Family Health team when facing situations involving flooding and the need to assist the affected population. In this context it was possible to see the lack of preparedness and the fragility of the team when it came to dealing with such a situation. The probability of new disasters reinforces the need to implement an educational strategy that is capable of empowering the Family Health teams when it comes to dealing with these extreme conditions in a holistic and resolute format.

\section{GUIDING QUESTIONS}

In what way can the PEH be used as a strategy with regard to facing natural disasters? Will the implementation of a situational strategic plan (SSP) as a PEH device guide the Family Health team with regard to facing natural disasters? Will the creation of guiding instruments be able to assist the Family Health teams in territorial action in the event of natural disasters?

\section{AIMS}

To analyze the use of a SSP as a PEH device in a Family Health team to prepare them for facing natural disasters; to identify the potential of a SSP as a tool during natural disasters; to formulate mechanisms (guiding instruments) that assist the Family Health team in engaging 
in territorial action during the occurrence of natural disasters.

\section{METHOD}

This is a intervention type of research which adopts a qualitative approach. The SSP(3) will be used as a PEH device in Family Health groups/ teams, through circle meetings, during the period from December 2013 to May 2014. It is intended to identify the problems experienced by professionals and by the community, determine their causes, design action/intervention plans to eliminate and/or minimize these issues, besides assisting in elaborating guiding questions that can assist the Family Health team in territorial health actions in the event of natural disasters. The subjects of this research are the members of Family Health teams and six residents of a community located in Vargem Grande district, in the municipality of Teresopolis - a total of 18 subjects, according to the following criteria with regard to inclusion and exclusion. The inclusion criteria are: professionals who have worked for at least two years in Family Health, and who have experienced disasters. The exclusion criteria are: undergraduate students in the area of health and professionals without any bond with the community. The subjects of this study will be asked to sign a Free and Clear Consent Agreement, according to the Brazilian National Health Council Resolution \#466, of December $12^{\text {th }}$ 2012. The data analysis will be done from the moment of construction of the four stages of SSP, and in accordance with the analysis of the content, understood as a set of techniques of analysis of communication.

\section{REFERENCES}

1. Ferreira GSM, Ponte KMA, Aragão AEA, Arruda LP, Ferreira IS. Continuous education of professionals in the hospital environment: an exploratory study. Online braz j nurs [periodic online]. [2012 Oct 11]; Suppl 1:488-91. Available from: http:// www.objnursing.uff.br/index.php/nursing/article/view/3874

2. Brasil. Ministério da Saúde. Secretaria de Gestão do Trabalho e da Educação na Saúde. Departamento de Gestão da Educação em Saúde. Política Nacional de Educação Permanente em Saúde. Brasília: Ministério da Saúde, 2009.64 p.

3. Abrahão AL, Souza AC, Marques D. Estratégia Saúde da Família: desafios e novas possibilidades para a atenção básica em saúde. Niterói: Editora da UFF, 2012. 205p.

\section{Data of the Project}

Project of dissertation of the Professional Master Program in Education in Health of the Fluminense Federal University.

Tutor: Ana Lúcia Abrahão

Email: brunabrunofisio@hotmail.com

Received: $29 / 08 / 2013$

Revised: 02/09/2013

Approved: 04/09/2013 